\title{
STATE SALES AND USE TAXATION IN INTERSTATE COMMERGE: CONGRESS MAKES SOME SUGGESTIONS
}

\author{
This note examines critically the recommendations of the Spe- \\ cial Subcommittee of the House Judiciary Committee on State \\ Sales and Use Taxation, and the resultant bill proposed to Con- \\ gress.
}

\section{INTRODUCTION}

$\mathbf{T}$ HE RECENT publication of a special congressional Subcommittee's report $t^{1}$ on state taxation of interstate commerce has provided Congress with an opportunity to alleviate the state tax problems of the multistate seller. Such action will be especially welcome in the area of sales and use taxation, where diversity of state law has long encumbered interstate transactions. ${ }^{2}$ The subcommittee report pro-

\footnotetext{
${ }^{1}$ Special Subcomm. of the House Comm. on the Judiciary, State Taxation of Interstate Commerce, H.R. REP. Nos. 565, 952, 89th Cong., Ist Sess. (1965). Volumes three and four constitute the final two of a full four-volume report. The latter two volumes deal with sales and use taxation and the recommendations of the Subcommittee, and are focal to this note. The first two volumes were released in 1962 and deal with state income taxation.

The report was authorized by Act of Sept. 14, 1959 (Pub. L. No. 86-272) 73 Stat. 555, 15 U.S.C. § 381 (1964), which was passed several months after the controversial decision in Northwestern States Portland Cement Co. v. Minnesota, 358 U.S. 450 (1959). In that decision the Supreme Court held that Minnesota could enforce a state income tax upon the net proceeds of' a foreign corporation which maintained a sales office within the state, but had no other contact within Minnesota. Mr. Justice Frankfurter dissented from the majority decision on the grounds that it was not the function of the Court to make the detailed study necessary to determine the burden of multistate taxation upon the interstate seller and thereupon balance that burden against the necessities of national economic life. Seemingly acting in response to $\mathrm{Mr}$. Justice Frankfurter's dissent, Congress passed the Act of Sept. 14, 1959, which excluded from state income tax jurisdiction situations involving mere solicitation of orders to be accepted at an out-of-state office. The law also authorized Congress to commence a study of the whole field of state taxation of interstate business. 73 Stat. 555, 556 (1959), I5 U.S.C. $\$ 381$ (1964). Compare Northwestern States Portland Cement Co. v. Minnesota, supra at 474-76 (Frankfurter, J., dissenting), with Special Subcomm. of the House Comm. on the Judiciary, State Taxation of Interstate Commerce, H.R. REP. No. 952, supra at 1121-28 [hereinafter cited as 1965 Special Subcomm. No. 952].

The sales tax is a general tax measured by the sale price, applying at a single rate to a broad variety of goods and services. The use tax, similar in effect and coverage, is a tax measured at a single rate based upon the sale price, but is imposed on the use, storage or consumption of the product within the taxing jurisdiction. The sales tax is based on the act of sale. The use tax normally exempts goods subject to a sales tax within the taxing jurisdiction and ordinarily falls upon goods sold out-of-state and transported to the taxing jurisdiction. In effect, the two taxes thus act as a single tax scheme. Since the focus of the report is upon the problems created by the require-
} 
poses to solve the diversity problem in the sales and use tax area by creating a system of uniform laws voluntarily enacted by each state and centrally administered by the Treasury Department. ${ }^{3}$

In order to establish this system, the Subcommittee recommended that Congress limit the noncomplying state's jurisdiction to enforce collection of sales and use taxes to situations where the multistate seller maintains a substantial presence within the boundaries of the state. ${ }^{4}$ Thus, the report contemplates that only sellers who maintain real estate holdings, make regular delivery of goods or have an employee operating entirely within the state may be required to collect and pay state sales and use taxes. ${ }^{5}$ However, for those states enacting the model law, such jurisdictional limitations would not apply; rather, collection responsibility for sales into enacting states will be nation-wide. ${ }^{6}$ Further, the proposed model law provides a uniform tax base and uniform procedures and re-

ments that the seller comply with a multiplicity of rules and regulations, it would seem that the source of those problems is the use tax, which allows a number of states to tax the same seller. See Special Subcomm. of the House Comm. on the Judiciary, State Taxation of Interstate Commerce, H.R. REP. No. 565, 89th Cong., 1st Sess. 607, 613-14 (1965) [hereinafter cited as 1965 Special Subcomm. No. 565].

Problems in the sales and use tax area had their roots in the Depression, when the states turned to a regressive tax to bolster flagging revenues. Id. at 609. Throughout the early period of the tax the states feared that the commerce clause precluded a sales tax on interstate business, and therefore applied the tax only to local sales. Id. at 613. This created the problem of protecting intrastate business from unfair competition with interstate business which was free from the state sales tax burden. Discrimination against local business caused so much concern that serious efforts to effect federal legislation in the area were ended only by the appearance of the use tax, which enabled the states to enact a comprehensive tax system affecting both interstate and intrastate business. Id. at 613-14; Hartman, Sales Taxation in Interstate Commerce, 9 VAND. L. REv. 138, 164-66 (1956). At this point the focus of the problem shifted from the state to the seller-collector, since a concurrent relaxation of jurisdictional due process impediments upon the state created uncertainty as to the extent which a state could exercise jurisdiction over the multistate seller. See 1965 Special Subcomm. No. 565, at $745-54$.

31965 Special Subcomm. No. 952, at 1133-38.

Id . at 1180.

- Ibid.

- A state within the collective system will have jurisdiction, bestowed by Congress, to enforce collection of a use tax by the seller of the goods without regard to physical or legal presence, domicile or contact. The one exception to this rule of nation-wide collection responsibility will be the small firm handling prepaid mail order sales. These sellers would not be required to collect taxes on sales attrihutable to any state in which only prepaid mail sales are made and the seller carries on no activity in the state other than advertising. The Subcommittee stated that the firm which handles prepaid mail orders has no effective way of collecting the tax from its customers, and therefore any collection responsibility would impose the tax upon the collector and not the customer. Moreover, the aggregate sales of such firms are not large. Id. at 1181-82. 
quirements for filing which the Subcommittee feels will solve the diversity problem confronting the interstate seller.7

In late October 1965, in response to the Subcommittee's recommendations, H.R. 11798 was submitted to the Congress. ${ }^{8}$ The bill contains the provisions for a uniform state tax system relating to interstate commerce. ${ }^{9}$ The section specifically dealing with the sales and use taxation contains a uniform law for adoption by the states on a voluntary basis. ${ }^{10}$ By containing provisions creating a uniform tax base and filing procedures and requirements, the uniform law presented in the bill carries out the proposals of the Subcommittee. In rendering the general recommendations into specific legislative proposals, the bill has in some instances resolved the problems suggested by the recommendations. In other instances, however, it has left them unchanged, or clouded even further.

\section{Constitutional Problems}

This suggested legislative course creates a number of new problems. Several of these are of a constitutional nature arising from the commerce and due process clauses. ${ }^{11}$

\section{A. Commerce Clause}

Congress is given the power by the Constitution to regulate commerce among the several states. ${ }^{12}$ This power has been held to be

IId. at 1181-87.

The subcommittee report envisions a uniform definition of "sale at retail" and contemplates that variations in the taxability of goods be limited only to the optional inclusion or exclusion of food and prescription drugs in the tax scheme of each state. Id. at 1183-84. This means that every saleable item except food and drugs would be subject to sales and use tax in states within the system. Such uniformity would alleviate the seller's burden of determining, for each state within which he sells, exactly which goods make up the tax base and are therefore subject to the sales and use tax. It does appear, however, that the seller would still be subjected to different tax rates on sales into different states. The report made no allusion to uniform rates, and thus has presumably left this determination to the individual states. This variance, while inconsistent with the goal of uniformity, may have been dictated by political exigency and does not detract from the benefits of a uniform collection structure.

${ }^{8}$ State Tax Rev., Oct. 27, 1965, p. 1.

- See text of H.R. 11798, 89th Cong., Ist Sess. (1965), reprinted in State Tax Rev., Oct. 27, 1965.

${ }^{10}$ H.R. 11798, 89th Cong., 1st Sess. $\$ 322$ (1965), reprinted in State Tax Rev., Oct. 27, 1965, pp. 34-40.

II Since H.R. 11798, 89th Cong., 1st Sess. $§ 101$ (1965), contains the jurisdictional requirements proposed by the Subcommittee's recommendations, see note 6 supra and accompanying text, the constitutional problems suggested will remain unchanged. See State Tax Rev., Oct. 27, 1965, p. 2.

12 U.S. CONST. art. I, $\S 8(3)$. 
exclusive where state regulation would tend to place any direct restrictions or other burdens upon the flow of goods through the national market. ${ }^{13}$ Where such is not the case, the states are left to their own designs until Congress speaks, after which they must yield to the congressional action where the two are in conflict. ${ }^{14} \mathrm{Al}$ though the regulation of interstate commerce falls within the exclusive power of Congress, the states are allowed to exercise their separate powers, even where that exercise tends to affect interstate commerce, ${ }^{15}$ so long as that commerce is not subjected to discriminatory ${ }^{10}$

${ }^{13}$ Where Congress does not make express regulations in an area of exclusive authority, state regulation has been deemed repugnant to the congressional implication that the area is to be left free from all regnlation. Robbins v. Shelby County Taxing Dist., 120 U.S. 489, 493 (1887); Brown v. Houston, 114 U.S. 622, 630-31 (1885); Reading R.R. v. Pennsylvania, 82 U.S. (15 Wall.) 232, 279-80 (1872). Those subjects of the commerce power which are in their nature national or admit only of one uniform system or regulation may be said to be of such nature as to require exclusive legislation by Congress. Cooley v. Board of Wardens ex rel. Society for the Relief of Distressed Pilots, 53 U.S. (12 How.) 299, 319 (1851); Northwestern States Portland Cement Co. v. Minnesota, 358 U.S. 450, 458 (1959) (dictum). See also Freeman v. Hewit, 329 U.S. 249, 252-53 (1946), where the limitation upon the states was delimited by a balancing of the interest in freedom of unimpeded national commerce and the local interest in regnlation. "To leave the matter to Congress allowing ... [the] states to tax 'to the fullest extent' until it intervenes, would run counter not only to the long-established rules requiring apportionment where incidence of multiple taxes would be likely, but also in substance and effect [run counter] to those forbidding discrimination, without the consent of Congress .... as well as the long-settled rule that the clause is 'of its own force' a prohibition upon the states." Id. at 279 (Rutledge, J., concurring).

14 Brown v. Houston, 114 U.S. 622 (1885) (Louisiana tax on goods as stock in trade upheld as applied to coal sold while moored on the Mississippi); Gwin, White \& Prince, Inc. v. Henneford, 305 U.S. 434, 455 (1939) (Black, J., dissenting); J. D. Adams Mfg. Co. v. Storen, 304 U.S. 307, 327 (1938) (Black, J., dissenting); Cooley v. Board of Wardens, ex rel. Society for the Relief of Distressed Pilots, supra note 13, at 319 (dictum). Cf. Freeman v. Hewit, supra note 13, at 279; Welton v. Missouri, 91 U.S. 275, 282 (1875) (license tax case indicating that congressional intention may be implied from legislation in other fields).

${ }^{18}$ Insofar as the exercise of state power affects interstate commerce in a situation where Congress has not acted to preempt the field, the court will balance local needs against the requirement of a nation-wide free market; and the type of power exercised by the state is an important factor in that balance. The taxing power is more narrowly limited because of its more threatening potential as a power to destroy. Freeman v. Hewit, supra note 13, at 252-53; McCulloch v. Maryland, 17 U.S. (4 Wheat.) 316, 431 (1819); McGoldrick v. Berwind-White Coal Mining Co., 309 U.S. 33, 48 (1940) (dictum). Cf. Brown v. Maryland, 25 U.S. (12 Wheat.) 419 (1827). For a general treatment of state taxing power as applied to interstate commerce, see Hartman, supra note 2, at 138; Kust \& Sale, State Taxation of Interstate Sales, 46 VA. L. REv. 1290 (1960); Menard, State Taxation of Interstate Commerce: From Form to Substance and Back Again, 18 OHIO ST. L.J. 9 (1957); Sinon, How Can the States Tax Interstate Commerce?, 32 TAXEs 914 (1954).

${ }^{18}$ A state regulation may discriminate either by providing a direct commercial advantage to local business or by subjecting interstate commerce to the burden of multiple taxation. Northwestern States Portland Cement Co. v. Minnesota, 358 U.S. 450, 
or undue burdens. ${ }^{17}$ Determining the extent of allowable state activity has been a function of the Supreme Court in the utilization of its power to construe the commerce clause. ${ }^{18}$ In the area of state taxation, the Court has declared that the commerce clause is not a vehicle for relief of the multistate business from its share of state tax burdens. ${ }^{19}$ Only where the taxing power of the state imposes multiple ${ }^{20}$ or discriminatory ${ }^{21}$ burdens on interstate commerce has it been held to conflict with the commerce clause. Where the tax is indirect, based upon some local incident, the Court has upheld it. $^{22}$ The Court has declared the use within the state after the

458,464 (1959) (apportioned tax on net income earned in state by foreign corporation upheld); General Trading Co. v. State Tax Comm'n, 322 U.S. 335, 338 (1944) (use tax upon sales solicited by salesmen, accepted by vendor out-of-state and sent to buyer by mail or common carrier upheld); Gwin, White \& Prince, Inc. v. Henneford, 305 U.S. 434, 438-39 (1939) (tax of $5 \%$ of gross receipts from marketing fruit shipped out-of-state unconstitutional); Brown v. Houston, 114 U.S. 622, 630 (1885) (property tax upon parish property upheld as applied to coal imported by river barge). Cf. McGoldrick v. Berwind-White Coal Mining Co., supra note 15, at 66.67 (Hughes, C. J., dissenting). In the latter case, Mr. Chief Justice Hughes argned that "it would seem to be extraordinary if a State could escape the restriction against direct impositions upon interstate commerce by first laying exactions upon its own trade and then insisting that in order to make its local policy completely effective it must be allowed to lay similar exactions upon interstate trade. That would apparently afford a simple method for extending state power into what has hitherto been regarded as a forbidden field." Ibid.

${ }^{17}$ Gwin, White \& Prince, Inc. v. Henneford, supra note 16, at 435, 439-40; Monamotor Oil Co. v. Johnson, 292 U.S. 86, 94-95 (1934); New Jersey Bell Tel. Co. v. State Bd. of Taxes and Assessments, 280 U.S. 338 (1930). See Freeman v. Hewit, 329 U.S. 249, 270.72 (1946) (Rutledge, J., concurring). See note 15 supra for an indication of the balancing test applied by the Court to determine the weight of the burden on interstate commerce.

${ }^{18}$ See Michigan-Wisconsin Pipe Line Co. v. Calvert, 347 U.S. 157, 166 (1954); Southern Pac. Co. v. Arizona ex rel. Sullivan, 325 U.S. 761,769 (1945); Freeman v. Hewit, supra note 17, at 279 (Rutledge, J., concurring); Northwestern States Portland Cement Co. v. Minnesota, 358 U.S. 450, 476 (1959) (Frankfurter, J., dissenting); McGoldrick v. Berwind-White Coal Mining Co., 309 U.S. 33, 69 (1940) (Fughes, C.J., dissenting).

${ }^{20}$ Northwestern States Portland Cement Co. v. Minnesota, supra note 18, at 461-62; McGoldrick v. Berwind-White Coal Mining Co., supra note 18, at 46, 49; Western Live Stock v. Bureau of Revenue, 303 U.S. 250, 254 (1938).

${ }^{20}$ Michigan-Wisconsin Pipe Line Co. v. Calvert, 347 U.S. 157, 166 (1954); Gwin, White \& Prince, Inc. v. Henneford, 305 U.S. 434, 439 (1949); Western Live Stock v. Bureau of Revenue, supra note 19, at 255-56 (dictum). See J. D. Adams Mfg. Co. v. Storen, 304 U.S. 307, 311 (1938). A multiple burden is the possibility that more than one state may, with equal right, impose similar levies upon the same article. Michigan-Wisconsin Pipe Line Co. v. Calvert, supra at 166.

${ }^{21}$ See note 16 supra.

22 Michigan-Wisconsin Pipe Line Co. v. Calvert, 347 U.S. 157, 166 (1954); Southern Pac. Co. v. Gallagher, 306 U.S. 167, 178 (1939); cf. Freeman v. Hewit, 329 U.S. 249, 270 (1946) (Rutledge, J., concurring); McLeod v. Dilworth Co., 322 U.S. 327, 355 (1944) (Douglas, J., dissenting). 
property is at rest to be such an incident, making the use tax a permissible subject of state action. ${ }^{23}$

Legislation along the line suggested by the Subcommittee's recommendation might be subject to attack by arguments similar to those interposed recently against the Act of September 14, 1959 (Pub. L. No. 86-272), the federal statute which froze state jurisdiction to collect income taxes from multistate business to certain situations involving minimal contacts while the Subcommittee's study was being made. ${ }^{24}$ The basic tenet of these prospective attacks may be hypothetically constructed as follows: the Supreme Court has effectively exempted the use tax from the strictures of the commerce clause by its holdings that such taxes do not burden interstate commerce since they are imposed on property only after it has come to rest in the state of use. ${ }^{25}$ The argument further contends that since states have the power to tax except where taxation interferes with an exclusive area of congresional jurisdiction such as regulation of interstate commerce, ${ }^{26}$ the power cannot constitutionally be taken away where there is no conflict. ${ }^{27}$ The Supreme

${ }^{23}$ General Trading Co. v. State Tax Comm'n, 322 U.S. 335 (1944); Felt \& Tarrant Mfg. Co. v. Gallagher, 306 U.S. 62 (1939); Southern Pac. Co. v. Gallagher, supra note 22; Henneford v. Silas Mason Co., 300 U.S. 577 (1937).

24 73 Stat. 555 (1959), 15 U.S.C. § 381 (1964); see note 1 supra. There have been three recent attacks on the constitutionality of this act in the state courts: International Shoe Co. v. Cocreham, 246 La. 244, 164 So. 2d 314, cert. denied, 379 U.S. 902 (1964); State ex rel. CIBA Pharmaceutical Prods., Inc. v. State Tax Comm'n, 382 S.W.2d 645 (Mo. 1964); Smith Kline \& French Lahs. v. State Tax Comm'n, 403 P.2d 375 (Ore. 1965). In each instance the state court rendered judgment for the taxpayer by up. holding the constitutionality of the act.

${ }^{25}$ General Trading Co. v. State Tax Comm'n, 322 U.S. 335 (1944); Felt \& Tarrant Mfg. Co. v. Gallagher, 306 U.S. 62 (1939); Southern Pac. Co. v. Gallagher, 306 U.S. 167 (1939); Henneford v. Silas Mason Co., 300 U.S. 577 (1937); see note 23 supra and accompanying text.

The cases cited in note 24 supra deal with the Act of Sept. 14, 1959 (Pub. L. No. 86-272), 73 Stat. 555, 15 U.S.C. \$ 381 (1964), which was designed solely to freeze state income tax jurisdiction. The rationale behind the cases in the income tax area is very similar to that used in the sales and use tax field. Both types of tax have been judicially determined not to be regnlations of interstate commerce of the type denied to the states in the absence of congressional action. Northwestern States Portland Cement Co. v. Minnesota, 358 U.S. 450 (1959) (income tax); Henneford v. Silas Mason Co., supra (use tax). There does not appear to be any substantial distinction between the income tax and sales and use taxes which would affect this type of argument, since all have been found to be local incidents. See Michigan-Wisconsin Pipe Line Co. v. Calvert, 347 U.S. 157, 166 (1954).

${ }^{26}$ See notes $15-19$ supra and accompanying text.

${ }^{27}$ See International Shoe Co. v. Cocreham, 246 La. 244, 261, 164 So. 2d 314, 320, cert. denied, 379 U.S. 902 (1964) (conflict did exist); State ex rel. CIBA Pharmaceutical Prods., Inc. v. State Tax Comm'n, 382 S.W.2d 645, 656 (Mo. 1964) (same); Taylor, House Study Finds State Taxation of Interstate Commerce Burdensome and Unfair, $21 \mathrm{~J}$. Taxation 120, 123 (1964). 
Gourt has previously found that no conflict exists in the sales and use tax situation, ${ }^{28}$ and thus Congress arguably is precluded from overruling such determinations.

A persuasive counterargument may be interposed to the above contentions, however. It may be asserted that these determinations by the Court have been mere constitutional delimitations defining a field of permissive state action. ${ }^{29}$ Viewed in this perspective, sales and use taxation of multistate business is an "overlap zone" of commerce regulation where states can act in the absence of congressional action. ${ }^{30}$ Supreme Court decisions have merely defined the constitutionally permissive limits of state action where Congress has not yet exercised its delegated power. ${ }^{31}$ Where the power delegated is exercised by Congress, the Court's prior decisions are thus immaterial, ${ }^{32}$ for by that exercise Congress itself permissibly defines the limits of state power. This view seems more consistent with the reasoning used by the Court to justify its limitations upon state taxation of interstate commerce. ${ }^{33}$ Moreover, this argument appears more compatible with the Court's permissive attitude toward congressional utilization of the commerce clause to effectuate national policies. ${ }^{34}$ Thus, an attack predicated upon the commerce clause is unlikely to thwart the proposed system or pose a significant threat to its validity.

\section{B. Due Process}

The second possible constitutional issue will likely arise in a due process context. ${ }^{35}$ Discussion in this area will probably be directed

${ }^{28}$ See, e.g., Michigan-Wisconsin Pipe Line Co. v. Calvert, 347 U.S. 157, 166 (1954); General Trading Co. v. State Tax Comm'n, 322 U.S. 335 (1944); Southern Pac. Co. v. Gallagher, 306 U.S. 167, 178 (1939).

${ }^{20}$ See Taylor, supra note 27 , at 123. 1965).

${ }^{30}$ Cf. Smith Kline \& French Labs. v. State Tax Comm'n, 403 P.2d 375, 379 (Ore. (1959).

${ }^{31}$ E.g., Northwestern States Portland Cement Co. v. Minnesota, 358 U.S. 450,458

${ }^{32}$ South Carolina State Highway Dept. v. Barnwell Bros., 303 U.S. 177, 189-90 (1938); International Shoe Co. v. Cocreham, 246 La. 244, 164 So. 2d 314, 320, cert. denied, 379 U.S. 902 (1964).

${ }^{33}$ See, e.g., Freeman v. Hewit, 329 U.S. 249, 254 (1946); Gwin, White \& Prince, Inc. v. Henneford, 305 U.S. 434, 441 (1939).

34 This permissive attitude seems to be expressed in a series of cases, culminating in Heart of Atlanta Motel, Inc. v. United States, 379 U.S. 241 (1964), and Katzenbach v. McClung, 379 U.S. 294 (1964).

${ }^{35}$ For a discussion of the role of due process in sales and use taxation see generally Hartman, supra note 2, at 171-76; Kust \& Sales, supra note 15, at 1303-09; 1965 Special Subcomm. No. 565, at 626-27. 
at the proposed jurisdictional limitations imposed upon states that do not enact the suggested model law. ${ }^{36}$ Under present judicial decisions, the due process limitation on state jurisdiction to enforce legal obligations is determined by a consideration of the relevant factors involved in the case in light of "our traditional conception of fair play and substantial justice."37 A number of recent cases have given some indication of the application of this subjective standard in the use tax field. In Miller Bros. Co. $v$. Maryland, ${ }^{38}$ the Supreme Court found insufficient contact $^{30}$ to justify assertion of use tax jurisdiction by Maryland where a Delaware seller sold acrossthe-counter to Maryland residents and advertised only through Delaware radio and newspapers and by mail circulars to former customers, some of whom were residents of Maryland. The seller did, however, make deliveries into Maryland.40 Giving the opinion of the Court, Mr. Justice Jackson alluded to the seller's difficulty in determining whether the taxable goods were to be used in Maryland. ${ }^{41} \mathrm{He}$ also mentioned the seller's freedom from Maryland's sales tax and stated that since the use tax is imposed upon the purchaser, "it would be a strange law that would make the taxpayer [seller] more vulnerable to liability for another's tax than to a tax on itself." 42 The Court thus found no jurisdictional basis in the facts of Miller Bros. upon which the state could enforce its use tax against the out-of-state seller. ${ }^{43}$ In a later case, Scripto, Inc. $v$. Carson, ${ }^{44}$ a variance in the facts was deemed sufficient to uphold the constitutionality of the tax. The Court found sufficient contact to hold a Georgia seller liable for the Florida use tax where sales were solicited in Florida through resident brokers working on a commission basis. The orders were then forwarded to the out-of-state offices for acceptance and ship-

\footnotetext{
${ }^{30}$ See note 4 supra and accompanying text.

${ }^{37}$ International Shoe Co. v. Washington, 326 U.S. 310, 320 (1945).

${ }^{88} 347$ U.S. 340 (1954).

${ }^{80} \mathrm{Mr}$. Justice Jackson, writing for the majority, indicated that "due process requires some definite link, some minimum connection, between a state and the person, property or transaction it seeks to tax." Id. at 344-45. He did not, however, delineate any critcrion for determining that minimum connection.

${ }^{40} I d$. at 341 .

11 Id. at 344 .

$12 I d$. at 346.

${ }^{43} \mathrm{Mr}$. Justice Jackson emphasized what may have been a major factor in the Court's decision: "Here was no invasion or exploitation of the consumer market in Maryland." Id. at 347. Without such a purposeful exploitation by the seller, the Court obviously felt it unfair to make the seller undertake duties which he would not otherwise have to accept.

$\$ 362$ U.S. 207 (1960).
} 
ment. ${ }^{45}$ The Court pointed out that the Florida tax was nondiscriminatory and that the taxpayer had ten resident jobbers soliciting in Florida on a commission basis. ${ }^{46}$ Given these findings, the Court pointed out that the collection of use tax by the out-of-state seller " 'is a familiar and sanctioned device' and ... Florida reimburses appellant for its service in this regard." 47

By contrast, under the proposed legislation, a seller operating within the factual setting in Miller Bros. would be taxable by states outside the system; for by making regular deliveries into Maryland, the seller has manifested that "substantial presence" which the report deemed sufficient to justify the invocation of jurisdiction by outsiders. ${ }^{48}$ No tax could be levied by an outsider in the Scripto situation, however, for the report does not contemplate the assertion of jurisdiction by a nonparticipating state where the seller has no property within the state, makes no regular deliveries there and maintains no employees solely within that state. ${ }^{49}$ In so limiting the jurisdiction of the states outside the proposed system, Congress may be faced with the argument that such a limitation is an unconstitutional usurpation of the judicial function of determining the jurisdictional limits in light of the constitutional restrictions inherent in the due process clause. This type of attack was made against the Act of September 14, 1959 (Pub. L. No. 86-272), ${ }^{\mathbf{5 0}}$ in several recent state cases. ${ }^{51}$ The Oregon court rejected the argument, stating that Congress by its action had not violated either the separation of powers doctrine or the due process clause. ${ }^{52}$ The

15 Id. at 209-10.

${ }^{10} \mathrm{Id}$. at 211. Mr. Justice Clark indicates that these factors are sufficient to supply the "definite link ... [the] minimum connection, between a state and the person, property, or transaction it seeks to tax," id. at 210-11, quoting from Miller Bros., which was missing from the Miller Bros. situation.

${ }^{47}$ Id. at 212. It appears that the Court here is referring to a practice indulged in by many states wherein a percentage discount is allowed the seller on taxes due to the states. Generally this amount will total two or three percent of the taxes collected. See 1965 Special Subcornm. No. 565, at 701-02.

18 1965 Special Subcomm. No. 952, at 1180.

10 Ibid.

60 73 Stat. 555 (1959), 15 U.S.C. $\$ 381$ (1964). See note 1 supra.

51 State ex rel. GIBA Pharmaceutical Prods., Inc. v. State Tax Comm'n, 382 S.W.2d 645, 654 (Mo. 1964); Smith Kline \& French Labs. v. State Tax Comm'n, 403 P.2d 375, 378 (Ore. 1965).

s2 Ibid. The Missouri court dealt with a similar line of argument, dismissing it with the short statement that "we do not find that the act overrules any U.S. Court decisions, since Congress and the Courts operate in different fields." State ex rel. CIBA Pharmaceutical Prods., Inc. v. State Tax Comm'n, supra note 51, at 667. The import of this assertion appears to be similar in meaning to the language of the Oregon court. 
Court proceeded to express the view that Congress, in limiting state jurisdiction to less than that allowed by the Supreme Court's delimitation of jurisdictional power under the due process clause, had not attempted to alter the Court's interpretation of due process. Rather, the Oregon court merely characterized the statute as a legislative determination that the states may not exercise the total jurisdictional reach allowed them by the due process clause and still remain within their allowable limits under the commerce clause as implemented by Congress. ${ }^{53}$ Although decisions in the state courts may thus be deemed both persuasive and favorable to the proposed law, until the issue is decided by the Supreme Court it will remain an area of uncertainty to the tax bar and the multistate seller. ${ }^{54}$

A second problem which may arise under the due process clause is that of congressonal power to expand the state jurisdictional reach into areas that the Supreme Court has held to exceed the permissible

${ }^{53} \mathrm{Mr}$. Justice Denecke in speaking for the Supreme Court of Oregon, stated that "we find the congressional action not to violate the doctrine of separation of powers or the Due Process Clause. The minimum contacts for jurisdictional nexus have not been changed by P.L. 86-272 [Act of September 14, 1959]. Congress cannot change the requirements of the Due Process Clause. Instead, Congress has found that it is wise ... to limit state taxation of interstate commerce. The Cougress has the power under the Commerce Clause, to remove or alleviate state-imposed burdens on interstate commerce. The boundaries of the federal commerce power do not coincide with the due process limits of state taxing power. Instead, the two powers overlap, and in the area of concurrence, the states may act unless Congress specifically prohibits." Smith Kline \& French Labs. v. State Tax Comm'n, supra note 51, at 378.

Mr. Justice Denecke's statement seems to deal exclusively with congressional action in limiting state jurisdiction. States outside the system may also attempt to attack the proposed statute by interposing the argument that the legislation changes the Court's construction of the due process clause to the detriment of mauy taxpayers by expanding the jurisdictional limits of the states within the system. The arguments advocated by the state courts in Smith and $C I B A$ will not be sufficient to dispose of this contention, for it is clear that extending the jurisdiction of the system does not have an effect upon the relationship between due process and jurisdictional nexus. The problem may be resolved by forbidding the states to argue the rights of their citizentaxpayers for lack of standing under the theory of Massachusetts v. Mellon, 262 U.S. 447 (1923). This would not dispose of the argument but would lessen the sources of attack.

${ }^{84}$ The due process problem has not come before the Court in this context in any prior case, for Congress has never passed legislation redefining the scope of judicial demarcations of the requisites of due process. See State ex rel. CIBA Pharmaceutical Prods., Inc. v. State Tax Comm'n, 382 S.W.2d 645, 654 (Mo. 1964). The interest of the tax bar and the administrators is indicated by the number of amici curiae briefs filed in the three state court cases. In $C I B A$, three states filed amici curiae briefs opting for the invalidity of the Act of September 14, 1959 (Pub. L. No. 86-272). Ibid. Twelve states filed such briefs in Smith Kline \& French Labs. v. State Tax Comm'n, supra note 51, and three taxpayers interposed briefs in favor of the legislation. Id. at 375-76. Similarly, nineteen states and two taxpayer representatives filed as amici curiae in International Shoe Co. v. Cocreham, 246 La. 244, 248, 164 So. 2d 314, 316, cert. denied, 379 U.S. 902 (1964). 
limits of due process. The subcommittee recommendations permit complying states to exercise jurisdiction under circumstances found by the court in Miller Bros. not to provide the requisite fairness. ${ }^{55}$ It is to be anticipated that a taxpayer might challenge such an extension, relying on arguments similar to those above-that Congress is exercising a judicial function by defining the limits of due process and contravening prior Supreme Court determinations of those limitations. Here, Congress would be specifically contradicting a decision as to the limits of fairness which the due process clause permits. In order to uphold the proposed legislation, however, the Court may rely on the subjective nature of the balancing test under the due process clause and distinguish Miller Bros. on grounds that congressional action would be a determinative factor not present in the Miller Bros. situation. Such a holding would be predicated upon the reasoning that the existence of congressional action in simplifying and consolidating jurisdiction and tax bases along the lines proposed would be the added factor needed to tip the scales of fairness in favor of state collection of the use tax in a situation like Miller Bros. Thus, the "fair play and substantial justice"s6 standard would not be changed under the circumstances. Only the circumstances would be changed.

\section{Practical Problems}

In addition to the constitutional problems presented by the recommended legislation, a number of pragmatic problems present themselves. Within the proposed law, the Subcommittee envisions a discretionary power in the states to exempt certain uses and purchasers. ${ }^{57}$ There are two methods of effecting this discretion. The first is to exempt the purchaser from having to pay the tax to the

\footnotetext{
Ex In Miller Bros. the Court found no justification for jurisdiction under the due process clause where the seller sold across-the-counter to Maryland customers at its store in Delaware and had no contact in Maryland except regular deliveries by the store's own trucks. See notes $38-43$ supra and accompanying text. The recommendations state that "a state may not require a seller to collect a sales or use tax unless the seller: . . (3) regularly uses his own vehicles or a private parcel service to make deliveries to private residences in the State." 1965 Special Subcomm. No. 952, at 1136.

${ }^{80}$ International Shoe Co. v. Washington, 326 U.S. 310, 320 (1945).

s7 1965 Special Subcomm. No. 952, at 1183.84. The Subcommittee did not enumerate its reasons for according the states this latitude to grant exemptions, although it ostensibly is desigued to allow for variances in state economic policies. Exemption guidelines are not provided by the Subcommittee, leaving the states to act wholly within their own discretion.
} 
seller. If this method is followed, the present problems of a seller with a multiplicity of exemptions are not eliminated, but are grafted onto the new system. ${ }^{58}$ The alternative is to require the purchaser to pay the tax to the seller, who remits to the state, which may then grant a refund to the purchaser. ${ }^{59}$ The seller would then have no problem with varying state exemptions and each state would only enforce one set of laws, designed to carry out its economic and social policies. The state might, however, tie up some revenue in floating funds to cover anticipated refunds, although remission to the purchasers directly from the federal treasury would alleviate this burden somewhat. ${ }^{60}$

The legislation proposed by H.R. 11798 approaches this problem by providing a discretion in the state of passing legislation granting immunity from the taxes through tax refunds by the states or immunity numbers. ${ }^{61}$ In the case of the tax refund system, it appears that the state will bear the administrative burden of the program.

${ }^{58}$ For a general treatment of collector problems with exemptions on a multistate level, see 1965 Special Subcomm. No. 565, at 649-53, 685-87. The problem generally is that the seller must make allowances for exemptions in collecting the tax from his customers. Since the exemptions vary from state to state, depending upon the economic policies which they pursue, a seller must vary his collection of sales and usc taxes accordingly. As the number of states within which the seller operates increases, his exemption problems multiply commensurately.

${ }^{89}$ There is some indication in the report that this is the method favored by the Subcommittee. The body of the recommendations for sales and use taxes contains only a general, ambiguous statement that "it appears practicable to leave room for a diversity of state views as to exempt purchasers and exempt uses of goods while at the same time eliminating the problems they have created for interstate sellers. The approach recommended is to absolve the seller of responsibility for any collection from buyers entitled to such exemptions.

"When it comes to the exemption of particular types of goods, however, a diversity of provisions among the states is incompatible with a workable cooperatively ad. ministered system." 1965 Special Subcomm. No. 952, at 1184. Taking the first and second paragraphs as a composite, it is unclear whether the Subcommittec favors exemptions in the collection process or refunds subsequent to collection. In its summary of the recommendations, the Subcommittee gave a further indication of its intentions. There it was stated that "no goods will be exempt, although each state will be free to grant refunds to purchasers." Id. at 1137. Seemingly, this statement indicates that the Subcommittee envisions uniform collection requirements with a power in the individual states to grant refunds to carry out particularized state economic policies.

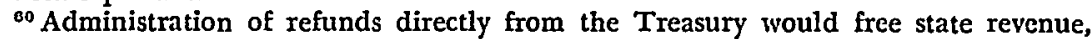
but at the same lime increase the administrative costs for which the state must recompense the Treasury. Under either method of refunding, exempted business funds are placed in temporary limbo. The antieipated problems will be lessened in the case of the recurrent buyer with a relatively stable refund. After the first year, accounting procedures will offset the amount of tax paid against the amount refunded to arrive at a static figure.

${ }^{\circ 1}$ H.R. 11798, 89th Cong., 1st Sess. § 321 (1) (1965), reprinted in State Tax Rev., Oct. 27, 1965, pp. 32-33. 
In such a case, the problem of revenue allocation would still be facing the state. $^{62}$ The immunity numbers, however, would be administered by the Treasury Department. ${ }^{63}$ Although it is not clear, the impression given by the uniform law suggested by H.R. 11798 is that the seller will be released from his collection duty if the purchaser presents his immunity number. ${ }^{64}$ Apparently, the risk of tax loss through false immunity numbers falls upon the state. If such is the case, the present problems that the seller has with exceptions ${ }^{65}$ would be solved. If not, however, those problems would still be with us. The solution to this decision lies entirely with the court.

The multistate seller will still have to cope with variances in filing requirements and tax base determinations between states outside the system and between in-system and out-system states. The hardship that these variances will cause the seller depends upon the number of states that remain outside the system. This suggests another problem confronting Congress. If the system is to work it must be attractive to a majority of states employing sales and use taxes, for its effectiveness lies in voluntary action by the states in enacting the model code and thus consolidating many statutes into one. Although there are cost and revenue advantages in a uniform administration, ${ }^{66}$ the main factor which will invite compliance is the jurisdictional restriction imposed upon the states outside the system. As indicated, there is a possibility that the limitation may encounter constitutional emasculation. If so, the system may well have no persuasive reason for joining it. Although such a judicial reaction does not seem likely, it will provide reluctant states with a rationale for inaction until set to rest by the courts.

62 The bill does not specifically provide for the administration of the refund system, although it does for the immunity number system. See note 63 infra and accompanying text. It is thus concluded that it is the states who are to administer the refunds.

For the problems the states would encounter in administering such a system, see note 60 supra and accompanying text.

${ }^{\text {os }}$ H.R. 11798, 89th Cong., 1st Sess. $§ 309$ (d) (2) (1965), reprinted in State Tax Rev., Oct. 27, 1965, pp. 23-24.

o4 See UNIform Sales and Use Tax LAw $\S \S 3-3,4-4$, reprinted in State Tax Rev., Oct. 27, 1965, pp. 38-39.

${ }^{65}$ See note 58 supra and accompanying text.

${ }^{\circ}$ For example, there will be an increase in state revenue from the occasional sale by the small, non-complying seller who often does not attract the attention of the state tax administrator and so escapes the collection responsibility. See 1965 Special Subcomm. No. 565, at 712. 
A widespread acceptance of the system will not ameliorate all difficulties. Even though the model law adopted by the states will create a uniform legislative tax scheme, it will be a state, not a federal law. As such, individual state court decisions of each state will be binding, even in the federal district courts. ${ }^{67}$ The result might be diversity in application of the otherwise uniform act since the courts of one state are not bound by the judicial interpretation given a uniform act in courts of a sister state. ${ }^{.8}$ Therefore, although the legislation will be uniform, application of the law may not be. ${ }^{69}$ Although this has not created insuperable problems for the efficacy of other uniform laws, ${ }^{70}$ there are indications that the state tax field is more susceptible to such disparate treatment by the states. $^{71}$

\footnotetext{
${ }^{87}$ Erie R.R. v. Tompkins, 304 U.S. 64 (1938).

${ }^{88}$ There is some indication that at least some jurisdictions in this country give uniform effect to decisions of sister states construing uniform laws or model statutes. E.g., Stewart v. Hansen, 62 Utah 281, 284, 218 Pac. 959, 960 (1923); Fidelity \& Cas. Co. v. Planenscheck, 200 Wis. 304, 309, 227 N.W. 387, 389 (1930). Other jurisdictions have given great weight to decisions of sister states on such laws, but have stopped short of according them controlling effect. E.g., Colley v. Summers Parrott Hardware Co., 119 Va. 439, 445, 89 S.E. 906, 908 (1916). There is, however, no compulsion to construe such acts uniformly. Although a state court has the responsibility of effectuating the designs of the legislature which passed the model act, it would also seem to owe a duty to the people of the state to act as a conservative influence in considering the interests involved on the individual level. While the legislature may feel that uniformity is desirable for some overall purpose, the court may have to deal with situations unique to the jurisdiction. In such a situation, it is questionable whether a court should give controlling weight to a decision rendered in another jurisdiction if it is to fulfill its function as arbiter of the interests of the citizens of its owu jurisdiction.

${ }^{\circ O}$ The tax field would seem to be more conducive of litigation than most, since both the taxpayer and the administrator are prone to litigate. Moreover, a system of taxation which affects interstate commerce should be free from conflicting interpretation.

${ }^{70}$ See, e.g., the Uniform Principal and Income Act (1931, 1962 acts), effective in twenty-three states; the Uniform Commercial Code (and its predecessor, the Uniform Sales Act), effective in thirty-two states and territories; the Uniform Reciprocal Enforcement of Support Act $(1950,1952,1958$ acts), effective in fifty-three states and territories. The widespread adoption of these acts over a period of years is not neces. sarily testimony to the fact that the uniform acts have been ideal, as indicated by con. stant revision. However, adoption by a substantial number of states does indicate that the acts have been found to be desirable for some purposes.

${ }^{71}$ See Studenski, The Need for Federal Curbs on State Taxes on Interstate Com. merce: An Economist's Viewpoint, 46 VA. L. REv. 1121, 1144-45 (1960), which points out that the states have consistently failed to take the initiative iu achieving uniformity in sales and use taxes. Since 1916 the National Tax Association has explored remedies for the problem without success. A host of others have walked the same barren path, including the National Association of Tax Administrators, the Controller's Institute, and the National Conference of Commissioners on Uniform State Laws. Id. at 1145 .
} 


\section{ConGLUSION}

There is no doubt that the sales and use tax problem demands solution. However, the legislation suggested by the Subcommittee contains enough inherent problems to caution Congress to examine the possible alternatives. One such alternative would be preemptive federal legislation similar to the model law, replacing all state sales and use taxes with one uniform scheme. This would effect the desired uniformity and eliminate the problem of inconsistent judicial interpretation. ${ }^{72}$ Any workable solution must ease the collection burden of the interstate seller without exposing the state taxing power to excessive federal control. If the Subcommittee's recommendations are the best compromise in this respect, perhaps they should be adopted in spite of their inherent difficulties. Nevertheless, in order to make the proposed system more attractive to the states without lessening its effectiveness, Congress should take note of these defects and consider possible alternatives to both the system proposed by the report and a preemptive federal system. Possible modifications of the proposed system include a single tax court to administer the system and thus provide uniform interpretation of the model act. Moreover, the Treasury's central administration should replace much of the states' own administration, or bear the cost from some other source in order to make it economical for the states to join. Pragmatically, the system must allow the states to grant exemptions in order to further their own divergent economic policies; yet, the exemptions must be administered in such a manner that they will not destroy the uniformity of the system. One answer is to allow rebates. ${ }^{73}$ Another possibility is a federal law creating a standard tax and procedural base for sales and use taxation of interstate commerce. The law would apply to all states and would not rely upon voluntary compliance. It could

\footnotetext{
${ }^{73}$ Having a single federal law in force in all fifty states with the consequent central administration and universal jurisdiction would bring uniformity to the sales tax field. Such a federal law would eliminate the problem of inconsistent judicial interpretation since any variation among the lower federal courts could be resolved with finality by appeal to the United States Supreme Court.

It might be possible to authorize a single court or judicial system to exercise jurisdiction in tax cases involving the proposed uniform system suggested by the Subcommittee. This would accomplish the same result as having a federal law, administered by the federal court system, although the states would in all probability be reluctant to surrender the authority of their judicial system to a superjudiciary.

${ }^{73}$ See note 59 supra and accompanying text.
} 
allow each state to determine the percentage of the sales price taxes $^{74}$ and to allow rebates. In any case, feasible legislation must create a balance between the local needs for revenue and economic planning and the national need for a uniform system for ease in administration.

\footnotetext{
"Although a variance in percentage rates would make the system less than uniform, the consequent burden on the seller would not be of large magnitude. See note 6 supra. On the othex hand, requiring a uniform rate ignores possible variations in state financial needs. Sales and use taxes are the major source of state revenue, and must, therefore, be allowed to vary from state to state with the need for that revenue.
} 